\title{
The Use of Complementary and Alternative Medicine in Turkish Patients with Rheumatic Diseases
}

\author{
Romatolojik Hastalığı Olan Türk Hastalarda Tamamlayıcı ve Alternatif Tıp Kullanımı
}

\author{
Hasan ULUSOY, ${ }^{1}$ Tülün Kaya GÜÇER, ${ }^{1}$ Murat AKSU, ${ }^{2}$ Şule ARSLAN, ${ }^{3}$ Abdülkadir HABİBOĞLU, ${ }^{3}$ Gürkan AKGÖL, ${ }^{1}$ \\ Ayhan BİLGíci, ${ }^{4}$ Ömer KURU, ${ }^{4}$ İlhan ÇETIN, ${ }^{5}$ Ayhan KAMANLI, ${ }^{1}$ Salih ÖZGÖÇMEN ${ }^{6}$ \\ ${ }^{1}$ Department of Physical Medicine and Rehabilitation, Division of Rheumatology, Medical Faculty of Firat University, Elazı̆̆, Turkey; \\ ${ }^{2}$ Department of Medical Ethics and the History of Medicine, Medical Faculty of Adnan Menderes University, Aydin, Turkey; \\ ${ }^{3}$ Department of Physical Medicine and Rehabilitation, Medical Faculty of Gaziosmanpaşa University, Tokat, Turkey; \\ ${ }^{4}$ Department of Physical Medicine and Rehabilitation, Division of Rheumatology, Medical Faculty of Ondokuz Mayıs University, Samsun, Turkey; \\ ${ }^{5}$ Department of Public Health, Medical Faculty of Gaziosmanpaşa University, Tokat, Turkey; \\ ${ }^{6}$ Department of Physical Medicine and Rehabilitation, Division of Rheumatology, Medical Faculty of Erciyes University, Kayseri, Turkey
}

Objectives: The aim of this study was to determine the prevalence of complementary and alternative medicine (CAM) use, to define the most frequently used CAM methods in rheumatic diseases, as well as to assess resources of information encouraging patients using CAM, and to evaluate the physicians' attitudes toward CAM use.

Patients and methods: We conducted face-to-face interviews with 318 patients with rheumatic diseases (212 females, 106 males; mean age $48.0 \pm 15.1$ years; range 18 to 79 years) regarding demographic variables, history of CAM use, preferred CAM methods and resources of information encouraging patients using CAM. Complementary and alternative medicine methods were categorized as follows; 1- Acupuncture, 2- Biofeedback, 3- Dietary modifications, 4- Body-based practices, 5- Magnetic or copper devices, 6- Behavioural methods, 7- Others.

Results: Approximately half of the patients (46.2\%) experienced at least one method of CAM previously. The most frequently used methods of CAM were dietary modifications (28.9\%) and body-based practices (16.4\%). Patients with non-inflammatory diseases used CAM more frequently compared to the patients with inflammatory diseases $(p=0.023)$. While $26.5 \%$ of the users were satisfied with the benefits of CAM, $73.5 \%$ believed that CAM was inadequate or useless. Most of the patients using CAM were encouraged by their relatives and mass media, whereas only $13.6 \%$ used CAM with the recommendation of their physician. One half of the physicians were indifferent in respect of CAM use.

Conclusion: Complementary and alternative medicine methods are commonly used among patients with rheumatic disorders. However, unfortunately, the most frequent resources of information on CAM are patients' relatives or mass media, rather than a health care professional. Therefore, physicians should be equipped with sufficient knowledge to inform their patients extensively on the use of CAM methods.

Key words: Alternative medicine; complementary therapies; rheumatic diseases.
Amaç: $\mathrm{Bu}$ çalışmada romatolojik hastalıklarda tamamlayıcı ve alternatif tıp (TAT) kullanım sıklığının ve en sık kullanılan TAT yöntemlerinin belirlenmesi ve bunun yanı sırahastaları TAT kullanımına teşvik eden bilgi kaynaklarının ve hekimlerin TAT kullanımı ile ilgili tutumlarının değerlendirilmesi amaçlandı.

Hastalar ve yöntemler: Romatolojik hastalığı olan 318 hasta (212 kadın, 106 erkek; ort. yaş 48.0 15.1 yıl; dağılım 18-79 yıl) ile demografik değişkenler, TAT kullanım öyküsü, tercih edilen TAT yöntemleri ve hastaları TAT kullanımına teşvik eden bilgi kaynakları ile ilgili yüz yüze görüşmeler yapıldı. Tamamlayıcı ve alternatif tıp yöntemleri; 1- Akupunktur, 2- Biofeedback, 3Beslenme değişiklikleri, 4- Vücut temelli uygulamalar, 5- Manyetik veya bakır cihazlar, 6- Davranışsal yöntemler ve 7- Diğerleri olarak kategorize edildi.

Bulgular: Hastaların yaklaşık yarısı (\%46.2) en az bir TAT yöntemini tecrübe etmişti. En sık kullanılan TAT yöntemleri beslenme değişiklikleri (\%28.9) ve vücut temelli (\%16.4) uygulamalardı. Hastalığı inflamatuvar olmayan kişiler, inflamatuvar olanlara kıyasla, daha sık TAT kullanmışlardı $(p=0.023)$. Kullananların $\% 26.5$ 'i TAT'וn faydalarından memnun iken, \%73.5'i yetersiz ya da etkisiz olduğuna inanıyordu. Tamamlayıcı ve alternatif tıp kullanan hastaların çoğu, yakınları veya kitle iletişim araçları tarafından teşvik edilmişti; yalnızca \%13.6'sı hekimlerin önerisi doğrultusunda TAT kullanmıştı. Hekimlerin yarısı TAT kullanımı konusunda ilgisizdi.

Sonuç: Romatolojik hastalığı olanlar arasında TAT yöntemleri sıkça kullanılır. Ancak TAT hakkında en sık bilgi kaynağı bir sağlık çalışanı yerine, ne yazık ki, hasta yakınları veya kitle iletişim araçları olmaktadır. Bu nedenle, hekimler hastalarını TAT yönteminin kullanımı hakkında geniş olarak bilgilendirmek için yeterli bilgi donanımına sahip olmalıdır.

Anahtar sözcükler: Alternatif tıp; romatolojik hastalıklar; tamamlayıcı tedaviler.

Received: October 5, 2011 Accepted: January 10, 2012

Correspondence: Hasan Ulusoy, M.D. Fırat Üniversitesi Tıp Fakültesi Fiziksel Tıp ve Rehabilitasyon Anabilim Dalı, Romatoloji Bilim Dalı, 23119 Elazığ, Turkey.

Tel: +90 424 - 2478928 e-mail: ulusoyh@mynet.com 
Complementary and alternative medicine (CAM) has recently attracted attention due to its widespread use. Coincidently, there is considerable interest in CAM therapies among rheumatologists as well as a willingness to refer patients to providers for at least some of the CAM methods like acupuncture, behavioral medicine, biofeedback, psychotherapy, dietary prescription, and exercise interventions. ${ }^{[1,2]}$ Rheumatologic diseases are chronic, and usually progressive conditions cause pain, physical disability, and dependence on medications which do not always provide full symptom relief. It is therefore not surprising that rheumatology patients might consider therapies aside from those offered by mainstream rheumatologists and primary care physicians. ${ }^{[3]}$ Previous studies have revealed that the use of CAM is prevalent among patients with rheumatic diseases, with the frequency of CAM use being reported as between $22 \%$ to $95 \%$ depending on the country. ${ }^{[4-9]}$

To the best of our knowledge, the utilization of CAM in Turkish patients with rheumatic disorders has not been investigated before. Therefore, the primary objective was to determine the prevalence of CAM use and the most frequently used CAM methods among patients with rheumatic disorders in Turkey. A secondary aim was to assess the perceived effectiveness of CAM use, the sources of information which have motivated patients to use CAM, and the physicians' attitudes regarding the use of CAM.

\section{PATIENTS AND METHODS}

This study was designed as a cross-sectional survey of consecutive patients with rheumatic disorders attending rheumatology clinics of three university hospitals which are located in the cities of Elazı $\breve{g}$, Samsun, and Tokat in Turkey. A total of 318 patients (212 females, 106 males; mean age $48.0 \pm 15.1$ years; range 18 to 79 years) who had been diagnosed with a rheumatic disease and had sufficient intellectual ability to understand all questions were enrolled. Written informed consent was obtained from all participants, and face-to-face interviews were performed to collect data. A questionnaire soliciting self-reported knowledge of the use of CAM was used in the study in which items related to basic demographic variables, current or previous use of CAM for their rheumatic disorders, CAM methods (using a checklist), the perceived benefits of CAM methods (none, inadequately, moderately, adequately), and the sources of information that motivated the patients to use CAM were included.
To facilitate the interpretation, CAM methods were categorized as follows:

1. Acupuncture,

2. Biofeedback,

3. Dietary modifications (special diets, glucosamine \pm chondroitin, fish-oil, megavitamins and minerals, specific bacterial cultures, herbal remedies, garlic tablets),

4. Body-based practices (chiropractic or nonchiropractic manipulation, massage),

5. Magnetic or copper devices,

6. Behavioral methods (psychotherapy, meditation, yoga, spiritual direction),

7. Other (hyperbaric oxygen, music therapy, bee venom, snake venom, application of leeches, salves, or peloids). The medical records of the patients were checked for diagnoses.

Data was analyzed using descriptive statistics, Student's t-test for continuous variables, and the chi-square test for categorical variables. A twotailed $p$ value of $<0.05$ was considered statistically significant.

\section{RESULTS}

A total of 318 patients with rheumatic disorders completed the questionnaire. The demographic and clinical characteristics of the patients are summarized in Table 1. Approximately one half (46.2\%) of the patients had experience with at least one type of CAM method. There was no difference in the frequency of CAM methods used among patients from the three different cities (data not shown). The mean age of CAM users and non-users was similar $(\mathrm{p}=0.156)$. There was no significant difference in terms of gender between CAM users and nonusers. However, the frequency of CAM use tended to be higher among females compared with males (50.5\% versus $39.6 \%$, respectively; $\mathrm{p}=0.095)$. Patients with a higher education level (more than 11 years of education) tended to use CAM more frequently than patients with a lower education level, but the difference did not reach a statistically significant level (64\% and $44.7 \%$, respectively; $\mathrm{p}=0.063)$. The patients with non-inflammatory or degenerative disorders, including osteoarthritis, fibromyalgia, chronic low back pain, and chronic neck pain, experienced CAM more frequently than the patients with inflammatory disorders, such as rheumatoid arthritis, spondyloarthropathies, connective tissue 
Table 1. Demographic and clinical features of 318 rheumatology patients with comparisons between CAM users and non-users

\begin{tabular}{|c|c|c|c|c|c|c|c|c|c|c|}
\hline & \multicolumn{3}{|c|}{ All patients } & \multicolumn{3}{|c|}{ CAM users } & \multicolumn{3}{|c|}{ Non-users } & \multirow[t]{2}{*}{$p$} \\
\hline & Mean \pm SD & Med. & Min.-Max. & Mean \pm SD & Med. & Min.-Max. & Mean \pm SD & Med. & Min.-Max. & \\
\hline Number & $318 \pm 100$ & & & $147 \pm 46.2$ & & & $171 \pm 53.8$ & & & \\
\hline Female & $212 \pm 66.7$ & & & $105 \pm 71.4$ & & & $107 \pm 62.6$ & & & 0.095 \\
\hline Age (years) & $48.01 \pm 15.05$ & & & $49.3 \pm 14.6$ & & & $46.9 \pm 15.4$ & & & 0.156 \\
\hline Education (years) & & 5 & $(0-15)$ & & 5 & $(0-15)$ & & 5 & $(0-15)$ & 0.186 \\
\hline Education >11 (years) & $25 \pm 7.9$ & & & $16 \pm 10.9$ & & & $9 \pm 5.3$ & & & 0.063 \\
\hline Inflammatory disorders ${ }^{*}$ & $167 \pm 59.4$ & & & $70 \pm 52.2$ & & & $97 \pm 65.9$ & & & 0.023 \\
\hline Non-inflammatory or & & & & & & & & & & \\
\hline degenerative disorders $\dagger$ & $114 \pm 40.6$ & & & $64 \pm 47.8$ & & & $50 \pm 34.1$ & & & \\
\hline Rheumatoid arthritis & $54 \pm 17$ & & & $22 \pm 15.0$ & & & $32 \pm 18.7$ & & & \\
\hline Spondyloarthropathies & $44 \pm 13.8$ & & & $22 \pm 15.0$ & & & $22 \pm 12.9$ & & & \\
\hline Connective tissue diseases $\ddagger$ & $44 \pm 13.8$ & & & $18 \pm 12.2$ & & & $26 \pm 15.2$ & & & \\
\hline Vasculitis\# & $17 \pm 5.3$ & & & $4 \pm 2.7$ & & & $13 \pm 7.6$ & & & \\
\hline Familial Mediterranean fever & $8 \pm 2.5$ & & & $4 \pm 2.7$ & & & $4 \pm 2.3$ & & & \\
\hline Osteoarthritis & $52 \pm 16.4$ & & & $31 \pm 21.1$ & & & $21 \pm 12.3$ & & & \\
\hline Low back pain & $37 \pm 11.6$ & & & $17 \pm 11.6$ & & & $20 \pm 11.7$ & & & \\
\hline Neck pain & $9 \pm 2.8$ & & & $5 \pm 3.4$ & & & $4 \pm 2.3$ & & & \\
\hline Fibromyalgia & $17 \pm 5.3$ & & & $11 \pm 7.5$ & & & $6 \pm 3.5$ & & & \\
\hline Other disorders & $36 \pm 11.3$ & & & $13 \pm 8.8$ & & & $23 \pm 13.5$ & & & \\
\hline
\end{tabular}

diseases, vasculitis, and familial Mediterranean fever $(\mathrm{p}=0.023)$.

The percentages of each CAM category ranged from $28.9 \%$ for dietary modifications to $0 \%$ for biofeedback in all of the study population. Body-based practices were the second most frequently used method of CAM (16.4\%). Behavioral therapies, acupuncture, and magnetic or copper devices were less frequently preferred methods (Table 2). The most frequently used CAM methods were vitamin \pm mineral supplements in $15.4 \%$, herbal remedies in $13.2 \%$, massage in $12.9 \%$, and fish-oil supplements in 9.4\% (Table 3).

Most of the users were motivated to use CAM by their friends and family members $(41.5 \%)$ or by other patients (17.7\%), and by mass media and advertising (12.9\%) (Table 4). The percentage of patients who decided to use CAM on their own was $14.3 \%$. Only $13.6 \%$ of the users had been referred by their physicians to use CAM therapies. Most of the users (60.5\%) did not desire to talk about their CAM use with their physicians. The rest of the users (39.5\%) expected to receive information about CAM from their physicians and talked about it with them. However, their physicians were frequently (50\%) incurious about the patients' CAM use, with $37.9 \%$ being in favor of it and $12.1 \%$ against the use of CAM therapies.

Only $26.5 \%$ of the patients who had used at least one CAM method considered these therapies to be adequate

Table 2. Frequency of use of each complementary and alternative medicine category by patients with rheumatic disorders

\begin{tabular}{lccc}
\hline Methods of CAM & In all patients $(\mathrm{n}=318)$ & & In CAM users $(\mathrm{n}=147)$ \\
\cline { 2 - 2 } & Mean \pm SD & & Mean \pm SD \\
\hline Dietary modifications & $92 \pm 28.9$ & $92 \pm 62.6$ \\
Body-based practices & $52 \pm 16.4$ & $52 \pm 35.4$ \\
Behavioral & $17 \pm 5.3$ & $17 \pm 11.6$ \\
Acupuncture & $13 \pm 4.1$ & $13 \pm 8.8$ \\
Magnetic or copper devices & $11 \pm 3.5$ & $11 \pm 7.5$ \\
Biofeedback & $0 \pm 0$ & $0 \pm 0$ \\
Others & $21 \pm 6.6$ & $21 \pm 14.3$ \\
\hline The "others" category includes salves, peloids, and application of leeches; CAM: Complementary and alternative \\
medicine; SD: Standard deviation.
\end{tabular}




\begin{tabular}{|lcc}
\hline $\begin{array}{l}\text { Table 3. Frequency of the use of different complementary and alternative medicine } \\
\text { methods by } 147 \text { complementary and alternative medicine users }\end{array}$ \\
\cline { 1 - 2 } Methods of CAM & In all patients (n=318) & In CAM users (n=147) \\
\cline { 2 - 3 } Mean \pm SD & Mean \pm SD \\
\hline Vitamin \pm mineral supplements & $49 \pm 15.4$ & $49 \pm 33.3$ \\
Herbal remedies & $42 \pm 13.2$ & $42 \pm 28.6$ \\
Massage & $41 \pm 12.9$ & $41 \pm 27.9$ \\
Fish-oil & $30 \pm 9.4$ & $30 \pm 20.4$ \\
Manipulations & $14 \pm 4.4$ & $14 \pm 9.5$ \\
Spiritual directions & $14 \pm 4.4$ & $14 \pm 9.5$ \\
Acupuncture & $13 \pm 4.1$ & $13 \pm 8.8$ \\
Glucosamine \pm chondroitin & $12 \pm 3.8$ & $12 \pm 8.2$ \\
Magnetic or copper devices & $11 \pm 3.5$ & $11 \pm 7.5$ \\
Salves & $9 \pm 2.8$ & $9 \pm 6.1$ \\
Psycotherapy & $8 \pm 2.5$ & $8 \pm 5.4$ \\
Peloids & $7 \pm 2.2$ & $7 \pm 4.8$ \\
Application of leeches & $7 \pm 2.2$ & $7 \pm 4.8$ \\
Kefir (a specific bacterial culture) & $5 \pm 1.6$ & $5 \pm 3.4$ \\
Garlic tablets & $5 \pm 1.6$ & $5 \pm 3.4$ \\
\hline CAM: Complementary and alternative medicine; SD: Standard deviation. & \\
\hline
\end{tabular}

or moderately effective whereas $73.5 \%$ considered them to be inadequate or not beneficial.

\section{DISCUSSION}

The results of this study showed that the use of CAM was common among patients with rheumatic disorders. The prevalence of CAM use was higher in non-inflammatory rheumatic disorders than inflammatory ones. Dietary modification was the most frequently used type of CAM. The next frequent type of CAM was body-based practices. The most frequent source of information on CAM came from patients' relatives or media rather than a healthcare professional. A small proportion of patients were motivated to use CAM by their physicians. Only one-fourth of the CAM users perceived that it had beneficial effects whereas the rest of the users thought it was either inadequate or not useful at all. Our results also indicated that female patients as well as

Table 4. Sources of information that motivated the patients to use complementary and alternative medicine

\begin{tabular}{lc}
\hline & Mean \pm SD \\
\hline Friends and family members & $61 \pm 41.5$ \\
Other patients & $26 \pm 17.7$ \\
Media and advertising & $19 \pm 12.9$ \\
Own opinion & $21 \pm 14.3$ \\
Physicians & $20 \pm 13.6$ \\
Total number of CAM users & $147 \pm 100$ \\
\hline SD: Standard deviation; CAM: Complementary and alternative medicine. \\
\hline
\end{tabular}

patients with higher education levels were more keen to use CAM.

In the present study $46.2 \%$ of patients with rheumatic disorders reported they had used CAM. This finding is in line with the results of previous studies from different countries. The percentage of rheumatology patients reporting CAM use varies from between $22 \%$ to $95 \%$ in different studies. In Canada, a study showed that $22 \%$ of people with self-reported arthritis had used CAM in the past year. ${ }^{[4]}$ In an Israeli study, $42 \%$ of patients with defined rheumatic diseases attending rheumatology clinics reported the use of CAM. ${ }^{[6]}$ In a Swedish study of patients with rheumatic diseases, it was found that $65 \%$ of the patients had used CAM at least once in their lives. ${ }^{[7]}$ Over $80 \%$ of patients with rheumatoid arthritis in Korea and $70 \%$ in Australia reported the use of CAM therapies. ${ }^{[8,9]}$ A study from the United States showed that $92 \%$ of patients with rheumatic diseases had used CAM methods for their arthritis. ${ }^{[10]}$ In a recent study on CAM use among patients with ankylosing spondylitis in Australia, 95\% of the patients reported previous or current CAM use. ${ }^{[5]}$ This wide range in the frequency of CAM use in studies from different countries may be related to cultural differences, availability of CAM providers, advertisements in the lay press, or methodologies used in these studies. For example, some of the studies used self-administered questionnaires with telephone or mail contact whereas others conducted face-toface interviews. Moreover, some studies focused only on one specific disease or used self-definition of 
rheumatic diseases while others used physician-based diagnoses and assessments.

Patients with inflammatory rheumatic diseases were less likely to use CAM than patients with noninflammatory rheumatic diseases. This finding is consistent with the results of previous studies. ${ }^{[6,11]}$ The availability of effective combination therapies for inflammatory rheumatic diseases, especially for rheumatoid arthritis, is a possible reason for these patients not seeking alternative therapies. Another hypothesis may be the fact that patients with inflammatory rheumatic diseases can be anxious due to possible interactions between conventional medical therapies and CAM therapies.

In this study, dietary modification was the most frequently favored (62.6\%) category of CAM for rheumatic diseases. The next most common (35.4\%) category of CAM was body-based practices, such as massage, manipulation and traction. In North American studies, chiropractic medicine was the most commonly used CAM method (from 31\% to 59\%) in rheumatic diseases whereas acupuncture and homeopathy were less common. ${ }^{[4,12,13]}$ In Israel, the most frequently used CAM therapies by patients with rheumatic diseases were acupuncture and homeopathy ( $44 \%$ and $41 \%$, respectively), and the frequency of dietary modifications was $26 \% .{ }^{[6]}$ In Sweden, most of the patients with rheumatic diseases (51.5\%) preferred to use dietary CAM methods with omega-3 fatty acids being the most frequently utilized type of dietary CAM. Acupuncture and manual therapies (massage, homeopathy, chiropractics) were preferred less frequently $(22.5 \%$ and $29.5 \%$, respectively) in the same study. ${ }^{[7]}$ In Britain, dietary modifications were the most common type of CAM method. ${ }^{[14]}$ Disease-specific studies showed that $23 \%$ to $72.1 \%$ of patients with ankylosing spondylitis used dietary modifications..$^{[5,15]}$ Lee et al. ${ }^{[8]}$ reported that $70.4 \%$ of patients with rheumatoid arthritis in Korea used products derived from plants or animals. The different frequency of use of each CAM method among different countries may reflect to some extent the availability of CAM providers, ethnic familiarity with some modalities, or coverage by public health insurance. For example, CAM has been accepted as a major form of healthcare and is partially covered by the medical insurance systems in some of the eastern countries. ${ }^{[16]}$

We found that CAM users were principally informed and motivated by their friends, family members, other patients, or mass media rather than by a healthcare professional. This is similar to the results of previous studies assessing the use of CAM. ${ }^{[6,8,17]}$ Only $13.6 \%$ of the users had been referred by their physicians in our study. On the other hand, less than half (39.5\%) of the users had discussed the use of CAM with their physicians, who were frequently indifferent toward the use of CAM by their patients. Previous studies revealed that patients are reluctant to report or discuss their CAM use with their physicians, and some discontinue prescribed treatments without consulting their physician. ${ }^{[13,18,19]}$ Rao et al. ${ }^{[13]}$ reported that $45 \%$ of patients with rheumatic diseases who had used CAM previously informed their physicians about their CAM use. In a study from the United States, only 54\% of patients with rheumatic diseases discussed their CAM use with their rheumatologist. ${ }^{[10]}$ Because chronic musculoskeletal disorders are the leading indication for the use of CAM, rheumatologists should inform their patients regarding its use. ${ }^{[20]}$ More patients are likely to inform their rheumatologist about their CAM use if their doctors prefer to use treatment methods which were shared and discussed with the patients. ${ }^{[10]}$

In our study, most of the users perceived the efficacy of CAM to be either deficient or ineffectual. Only one-fourth of the users were satisfied with the benefits of CAM therapies. In previous studies, less than half of the patients with rheumatic diseases reported symptomatic benefits of CAM use. ${ }^{[5,8]}$ In a recent study, half of the patients who had experienced at least one CAM drug stated that the drug had positive effects on their health. ${ }^{[7]}$

Previous studies have indicated that female gender, advanced education level, and younger age are associated with a higher prevalence of CAM use in rheumatic diseases. ${ }^{[4-7,9,21,22]}$ Similarly, female gender and higher education levels (more than high school) were also associated with more frequent use of CAM in our study. On the other hand, a lower education level was found to be associated with a greater use of CAM in different study. ${ }^{[23]}$

A notable strength of this study is the representative sampling of patients with rheumatic diseases from the three clinics in different cities of Turkey. The number of surveyed patients was sufficient compared with previous studies which assessed CAM use. On the other hand, this study had a number of limitations. The results of the study depended on self-reported data. The benefical effects of each of the CAM modalities were also obtained from patient-reported data. We should underscore that the benefits of CAM modalities have 
to be assessed by using evidence-based methods. In addition, there is always a question mark regarding what does or does not constitute a CAM therapy. For example, current Osteoarthritis Research Society International (OARSI) guidelines list acupuncture and glucosamine, either with or without chondroitin, as non-pharmacologic treatments for hip and knee osteoarthritis. ${ }^{[24]}$ However, we selected to include these therapies under CAM. The American College of Rheumatology defined CAM as therapies "outside of the prevailing scientific mainstream but [which] still may be safe and effective, unsafe and ineffective, or questionable". ${ }^{25]}$ The concept of CAM has changed over time. Currently, for example, exercise interventions and balneotherapy are considered as integral parts of mainstream medical treatments. ${ }^{[25-27]}$ Therefore, we decided not to include these therapies in CAM and to consider them as conventional therapies.

It is clear that patients' use of CAM is an important clinical issue; this is especially true for rheumatologists and primary care physicians who treat rheumatologic disorders. Unfortunately, the most frequent sources of information about CAM are derived from patients' relatives or mass media rather than healthcare professionals. Because the use of CAM may negatively affect patients by causing an interaction with prescribed medications or a deferral of effective therapy, physicians should be ready to extensively inform their patients about the use of various CAM methods.

\section{Declaration of conflicting interests}

The authors declared no conflicts of interest with respect to the authorship and/or publication of this article.

\section{Funding}

The authors received no financial support for the research and/or authorship of this article.

\section{REFERENCES}

1. Berman BM, Bausell RB, Lee WL. Use and referral patterns for 22 complementary and alternative medical therapies by members of the American College of Rheumatology: results of a national survey. Arch Intern Med 2002;162:766-70.

2. Manek NJ, Crowson CS, Ottenberg AL, Curlin FA, Kaptchuk TJ, Tilburt JC. What rheumatologists in the United States think of complementary and alternative medicine: results of a national survey. BMC Complement Altern Med 2010;10:5.
3. Quandt SA, Chen H, Grzywacz JG, Bell RA, Lang W, Arcury TA. Use of complementary and alternative medicine by persons with arthritis: results of the National Health Interview Survey. Arthritis Rheum 2005;53:748-55.

4. Fautrel B, Adam V, St-Pierre Y, Joseph L, Clarke AE, Penrod JR. Use of complementary and alternative therapies by patients self-reporting arthritis or rheumatism: results from a nationwide canadian survey. J Rheumatol 2002;29:2435-41.

5. Chatfield SM, Dharmage SC, Boers A, Martin BJ, Buchanan RR, Maksymowych WP, et al. Complementary and alternative medicines in ankylosing spondylitis: a cross-sectional study. Clin Rheumatol 2009;28:213-7.

6. Breuer GS, Orbach H, Elkayam O, Berkun Y, Paran D, Mates $\mathrm{M}$, et al. Use of complementary and alternative medicine among patients attending rheumatology clinics in Israel. Isr Med Assoc J 2006;8:184-7.

7. Klingberg E, Wallerstedt SM, Torstenson T, Håwi G, Forsblad-d'Elia $H$. The use of complementary and alternative medicine in outpatients with inflammatory rheumatic diseases in Sweden. Scand J Rheumatol 2009;38:472-80.

8. Lee MS, Lee MS, Yang CY, Lee SI, Joo MC, Shin BC, et al. Use of complementary and alternative medicine by rheumatoid arthritis patients in Korea. Clin Rheumatol 2008;27:29-33.

9. Buchbinder R, Gingold $M$, Hall S, Cohen M. Nonprescription complementary treatments used by rheumatoid arthritis patients attending a communitybased rheumatology practice. Intern Med J 2002;32:208-14.

10. Sleath B, Callahan LF, Devellis RF, Beard A. Arthritis patients' perceptions of rheumatologists' participatory decision-making style and communication about complementary and alternative medicine. Arthritis Rheum 2008;59:416-21.

11. Rao JK, Kroenke K, Mihaliak KA, Grambow SC, Weinberger M. Rheumatology patients' use of complementary therapies: results from a one-year longitudinal study. Arthritis Rheum 2003;49:619-25.

12. Kaboli PJ, Doebbeling BN, Saag KG, Rosenthal GE. Use of complementary and alternative medicine by older patients with arthritis: a population-based study. Arthritis Rheum 2001;45:398-403.

13. Rao JK, Mihaliak K, Kroenke K, Bradley J, Tierney WM, Weinberger M. Use of complementary therapies for arthritis among patients of rheumatologists. Ann Intern Med 1999;131:409-16.

14. Ernst E. Complementary and alternative medicine in rheumatology. Baillieres Best Pract Res Clin Rheumatol 2000;14:731-49.

15. Haugen M, Kjeldsen-Kragh J, Nordvåg BY, Førre O. Diet and disease symptoms in rheumatic diseases--results of a questionnaire based survey. Clin Rheumatol 1991;10:401-7.

16. Kim CY, Lim B. Modernized education of traditional medicine in Korea: is it contributing to the same type of professionalization seen in Western medicine? Soc Sci Med 2004;58:1999-2008. 
17. Shin YI, Yang CY, Joo MC, Lee SG, Kim JH, Lee MS. Patterns of Using Complementary and Alternative Medicine by Stroke Patients at Two University Hospitals in Korea. Evid Based Complement Alternat Med 2008;5:231-5.

18. Eisenberg DM, Davis RB, Ettner SL, Appel S, Wilkey S, Van Rompay M, et al. Trends in alternative medicine use in the United States, 1990-1997: results of a follow-up national survey. JAMA 1998;280:1569-75.

19. Azaz-Livshits T, Muszkat M, Levy M. Use of complementary alternative medicine in patients admitted to internal medicine wards. Int J Clin Pharmacol Ther 2002;40:539-47.

20. Perlman AI, Eisenberg DM, Panush RS. Talking with patients about alternative and complementary medicine. Rheum Dis Clin North Am 1999;25:815-22.

21. Zochling J, March L, Lapsley H, Cross M, Tribe K, Brooks P. Use of complementary medicines for osteoarthritis-a prospective study. Ann Rheum Dis 2004;63:549-54.

22. Moore AD, Petri MA, Manzi S, Isenberg DA, Gordon C, Senécal JL, et al. The use of alternative medical therapies in patients with systemic lupus erythematosus. Trination Study Group. Arthritis Rheum 2000;43:1410-8.

23. Ramos-Remus C, Gutierrez-Ureña S, Davis P. Epidemiology of complementary and alternative practices in rheumatology. Rheum Dis Clin North Am 1999;25:789-804.

24. Zhang W, Moskowitz RW, Nuki G, Abramson S, Altman $\mathrm{RD}$, Arden N, et al. OARSI recommendations for the management of hip and knee osteoarthritis, part I: critical appraisal of existing treatment guidelines and systematic review of current research evidence. Osteoarthritis Cartilage 2007;15:981-1000.

25. Panush RS. American College of Rheumatology position statement: complementary and alternative therapies for rheumatic diseases. Rheum Dis Clin North Am 2000;26:189-92.

26. Sukenik S, Flusser D, Abu-Shakra M. The role of spa therapy in various rheumatic diseases. Rheum Dis Clin North Am 1999;25:883-97.

27. Zochling J, van Der Heijde D, Dougados M, Braun J. Current evidence for the management of AS: a systematic literature review. Ann Rheum Dis 2006;65:442-52. 